\title{
The Effects of Diversity Management on Employee Intention to Quit: Mediating Role of Employee Motivation
}

\author{
Hifza Saif \\ Post RN, the Superior College, Department Of Nursing
}

\begin{abstract}
Employee is a bloodstream of any organization. Accomplishment of any organizational goal is depending on employees performance. Aim of Study: The purpose of this study is to examine the effect of DM on the employee, intention to quit with the mediating role of EM. Methodology: The implementation of this research is conducted on charge nurses of intensive care units in tertiary hospital. Collection of data was done from 121 people from both genders. The purpose of this study is to examine that how the diversity management can reduce turnover intention and how motivation can improve the work performance and help to reduce employees intention to quit. Results: By using multiple regression tests, the results shows the significant negative correlation between diversity management and employee intention to quit also discussed that mediation exist in this relationship. Conclusion: The results of this study shows that diversity management practices can help to reduce turn over intention and motivation can help to manage the diversity that can lead to retention of the employees in the organization.
\end{abstract}

Keywords: diversity management, employee intention to quit, employee motivation.

DOI: $10.7176 / \mathrm{JHMN} / 79-04$

Publication date:August $31^{\text {st }} 2020$

\section{INTRODUCTION}

Diversity management has become much important over the past few decades and becoming an important part of human resource management in any organization. However, there are many evidences of positives effects of diversity on organization along with the subordinate. DM has becoming much important in the academic as well as practitioner literatures(Kundu, Mehra et al. 2017). So, In DM initiatives the equal employment opportunities are rooted in fixed routine business practice and organization should maintain these practices. Diversity indicates the singularity that a person brings a lot of experience, whether in age, thinking, work experience, gender, education, and religion (Wang 2016). In an organizational strength, diversity has modified by having a formal and legally accountability to a design order. A corporation either international or not is influenced by global diversity may be directly or indirectly(Agarwal and Bhargava 2014). (Patrickson, O'Brien et al. 2001) argue that diversity practices can be different in different countries and areas due to geographic and environmental reasons and the results may vary in different areas. Somehow, the organizational policies can lead to employee turnover intention. Turnover intention and decision of turnover reflected the reduced level of employees and of work life. There are several reasons for turnover intention for example organizational and individual factors that influence physical and psychological status of employees. Turnover intention was reduced when employees had high intrinsic motivation (e.g., career development) and extrinsic motivation (e.g., salary;(Houkes, Janssen et al. 2003, GETACHEW 2017)

Diversity is a multi-dimensional concept, primary diversity and secondary diversity. Primary dimensions are human's inborn traits such as nationality, age and gender that are important for the early life and socialization process. Secondary dimension includes different characteristics such as cognitive and skillful techniques (work experience, organizational tenure, personality and educational level). In management literature the effects of organizational diversity have been discussed widely (Hsiao, Auld et al. 2015). Any organizational task can be achieved by application of diversity management. The desirable goal includes promoting organizational justice and incorporation, decrease prejudice and good financial support (Kossek \& Pichlor 2006). Many researchers found that diversity have the positive effects along with the negative effects on organization. Actual impact of diversity depends on personal factor and organizational policies (Chen and Choi 2008). (Sourouklis and Tsagdis 2013) in 23 relevant research papers the organizational diversity has positive effect on varies performance indicators such as staff turnover, satisfaction and productivity.

Diversity is incorporated throughout the organization, from the top to bottom. Effective diversity can increase organization performance. When the subordinate receiving socioeconomically benefits from the organization then they try to act their abilities in a favourable way(Magoshi and Chang 2009). Employee satisfaction level remains high when diversity environment is positive and high, because the subordinates thought that the organization cares about themselves. The employees want to continue their job that result in decrease turnover intention (KristofBrown et al., 2002). By studying the EM, the employee behaviour as readiness which reflect the employee's outcome in any organization that further lead to their tendency to continue (Lorse, \& Boivin, 2010). So, motivation can change the attitude and improve meaningful work which can result in promotion of intrinsic motivation and reduce turn over intention. Intrinsic motivation just like doing any activity just for mental satisfaction and enjoyment that has very important role for extrinsic motivation and reducing turnover intention.(Amabile 1993, 
Deci and Ryan 2004) Thus, the effect of DM on motivation will authorize its uses in the form of considerable HR plan to build up employee performance. Many studies had showed that employees working attitude and job behavior is directly and strongly influenced by good HR practices. (Agarwala 2003;Gong et al., 2010;Guchait and Cho, 2010)

Many researchers have done work about specific purposes. In western nations many researches have done work on diversity management (Peretz, Levi, and Fried, 2015) and those studies did not reveal the Asian economic condition that is definitely changing on the basis of culture. In Asia there is significant growth of hospitality industry and other diverse organizations but the available literature is very limited (Winter 2009). Very few studies are available on multiple employment outcomes regarding diversity and its effects. So the recent study is therefore conducted to check the effect of diversity management in various organizations in Asian countries.

The present study aims to assess the effects of DM on employee intention to quit with the mediation of EM in Asian context. Organizational diversity is getting much importance in hospitality industry, nursing profession and other industries. Organizational diversity and DM related program can decrease turnover intention or rate of burnout. Motivation can also affect the quality and quantity of performance. Condition of incentive has the positive effect on work performance. The goal of successful diversity practices is to frame the diversity as a opportunity and challenge instead of threat and difficulty to defeat (Jayne \& Dipboye,2004; Howard-Grenville \& Hoffman, 2003). This study will help to organize a diverse environment in a better way and diversity practices will increase the motivation level and employees retention in any organization. Turnover intention and burnout reduce the morale of other employees. Organizational policies and memories are at risk at the time of orientation to new employees. If diversity practices not apply in organization, this can lead to decline motivation level and employee retention. It's very essential to study effects of the diversity on employee attention to quit with mediating role of employee motivation.

\section{Literature review}

Social identity theory can be applied in hospitality and other work fields when studying organizational diversity(Furunes and Mykletun 2007). Group membership and individual uniqueness has an important role in shaping behavior, beliefs and attitudes. Gender and ethnicity (demographic factors) figure the vital diversity in any organization. (Singal 2014) explain that increasing diversity in organizations, these organizations must make some plan to hire most talented staff who works for the betterment of organization. People with characteristics related to organization. (tenure and hierarchical position) also has the diversity (Kim, Murrmann et al. 2009). Studies shows that the important aspect of diversity is having subordinates from different ethnic background can improve return on investment, innovation and organization performance (Richard, 2000).similarly DM and EM practices can result in higher level of productivity and retention of employees in the organization ( Evans, 2014; Armstrong et al., 2010; Bridgstock et al., 2010).. Employee turnover can be describes as movements of group of employee that can generate the chances of valances within organizational unit. (Beach et al., 2003, p.49). Many personal and ethnic factors that added to turnover(Yang, Wan et al. 2012). High turnover can negatively affect the morale of remaining employees and especially when the work relies on team performance. Researches show that turnover may decrease the agency productivity and performance (Cho and Lewis 2012). Orientation about organization policies and organizational memories to new employees are at risk (Moynihan and Landuyt 2009). Research shows that variables such as age (Magd 2003), tenure (Armstrong-Stassen 2001) and education level (Royalty 1998) related to job and turnover has relationship of a range of diversity.(Hinkin and Tracey 2000) suggest that organizational diversity and diversity management related program can decrease turnover intention or rate of burnout. Diversity management and encouraging diverse workforce can help to increase job satisfaction and decrease the rate of turn over intention (Choi and Dickson 2009). When the subordinates were mentally satisfied to their organization and value the organizational goals, their turn over intention tented to be lower (Bright, 2008). Turnover intention can be decrease with intrinsic motivation of employees for example career development and extrinsic motivation for example rewards promotion and appreciation. (Houkes, Janssen, Jonge, \& Bakker, 2003; Iverson \& Roy, 1994) Motivation can also affect the quality and quantity of performance. Condition of incentive has the positive effect on work performance. Motivation is the basic component of employee performance and outcome. Intrinsic and extrinsic both are the work motivation factors, inner feelings and wish to perform a task related to intrinsic factors and extrinsic factors includes external to the individual and not related to the task that they are performing (Ryan and Deci 2000). intrinsic motivation need for appreciation, achievement and positive feedback that can improve work performance. Extrinsic motivation emphasizes external rewards such as workplace characteristics, benefits, pay, incentives and positive relationship with colleagues and higher authority that can improve work performance and employee retention (Pinder 2014). Experimental research has shown that government employee put great effort to help others and for the benefits of society than the private sector (Houston, 2006; Lewis \& Frank, 2002). Diversity practices of any organization support the employees from all background. The goal of successful diversity practices is to frame the diversity as a opportunity and challenge instead of threat and difficulty to defeat (Jayne \& Dipboye,2004; Howard-Grenville \& Hoffman, 2003).when 
organization try its best to facilitate and support its employees then the employees will respond positively in their work roles (Maslach, Schaufeli et al. 2001). Previous researches show that diversity practices can reduce the discrimination and employee work place behavior and attitude.

Many literature show that trust is a very important factor in diversity practices to a wide range of outcomes such as commitment and employee retention (Dirks and Ferrin 2002), employee role and extra task performance(Mayer and Davis 1999) (Madjar \& Ortiz-Walters, 2009). Positive HR activities can make a situation where all individuals and group react in a positive attitude including trust. HR activities in an organization that support the employees improve communication and empower employees can make a climate of trust and better place for work (Tzafrir, Harel et al. 2004)

\section{Methodology:}

This study is conducted to assess the effect of diversity on employee intention to quit, with mediating role of employee motivation. In this study Quantitative co-relational research design was conducted using structured questionnaire. Setting of the study will be the tertiary hospital setting of Lahore the children hospital Lahore and the targeted population will be the female nurses of the children hospital Lahore. The participants belong to different socioeconomic level and different demographic background. The participants will be female. Data will be collected from the participants through adopted questionnaire and the participants will be selected through convenient method. The sample size for the study will be 110 which was calculated from the slovins method. A self administer a modified version questionnaire on diversity was adopted from the studies of (Langford 2009) (Green, López et al. 2002). The scale for intention to quit was taken from (Boshoff and Allen 2000) study. Questionnaire on employee's motivation, adapted from (Skudiene and Auruskeviciene 2012). The questionnaire consists of two sections (section A) composed of demographic data which include age, gender, institution, marital status, years of experience and designation. (Section B) composed of the questionnaire regarding the diversity, employee intention to quit and employee motivation. Participants will be answer to the question according to the 5 liket scale. 5 point scoring format was used with (1) SA to (5) SD. Data collection plan is one of the main source to collect data. Self administered questionnaire will be used to collected data from the participants. There will be given a free hand to complete it and return it. Data analysis will be done by SPSS version 20 Statistical computer software for data analysis. This is a quantitative study and all quantitative statistics will be obtained through the SPSS software. The use of analysis aimed to identify the effects of emotional intelligence and political skills on the teacher's job satisfaction.

Charge nurses participated in this study. These nurses are working in tertiary hospital in intensive care units. Nurses who will participate voluntarily and give feedback. All participants are nurses. This study will approximately taken 6-7 months.

Consent will be taken from participants and free hand will be given to the participants to take part in studies or refuse to participate. Participants will have also be right to mentioned name or demographic data. Information regarding research will be provided to participants and this will be achieved via a consent form attached to the questionnaire. Confidentiality should be maintained about data and participants. To maintain the teachers confidentiality no one even principal of other researcher will allow reading the questionnaire. With the help of Nuremberg code of ethics rights of participants will be protected. 
Demographic analysis

\begin{tabular}{|c|c|c|}
\hline Table \# $01 \quad$ Demographic characteristic of respondents & $\mathbf{N}$ & $\%$ \\
\hline & 121 & 100 \\
\hline \multicolumn{3}{|l|}{ Gender } \\
\hline Male & 4 & 3.3 \\
\hline Female & 117 & 96.7 \\
\hline \multicolumn{3}{|l|}{ Age } \\
\hline $20-25$ years & 38 & 31.4 \\
\hline $26-30$ years & 60 & 49.6 \\
\hline $31-35$ years & 19 & 15.7 \\
\hline Above 35 years & 4 & 3.3 \\
\hline \multicolumn{3}{|l|}{ Marital Status } \\
\hline Married & 57 & 47.1 \\
\hline Single & 64 & 52.9 \\
\hline \multicolumn{3}{|l|}{ Qualification } \\
\hline General Nursing & 56 & 46.3 \\
\hline Specialization and Diploma & 44 & 36.4 \\
\hline Post RN & 20 & 16.5 \\
\hline Others & 1 & .8 \\
\hline \multicolumn{3}{|l|}{ Experience } \\
\hline $1-5$ years & 70 & $\mathbf{5 7 . 9}$ \\
\hline $5-10$ years & 35 & 28.9 \\
\hline $10-15$ years & 16 & 13.2 \\
\hline
\end{tabular}

In given table summarizes the characteristics of respondent $(\mathrm{n}=121)$ 0n the basis of gender ( Male and female), Age (20-25 years, 26-30 years, 31-35 years and above 35 years of age group), Marital Status (Married and single), Qualification (General Nursing, Specialization and Diploma, Post RN and others) and work experience (1-5 years, 5-10 years and 10-15 years of experience)

RELIABILITY AND VALIDITY ASSRSSMENT

Table \# $02 \quad$ Summary of reliability analysis

\begin{tabular}{ll} 
Variables & Cronbach Alpha \\
\hline Diversity management & .704 \\
Employee intention to quit & .813 \\
Employee motivation & .759 \\
\hline
\end{tabular}

Cronbach Alpha above .70 is considered to be the acceptable indicator of reliability

The alpha value of diversity management is .704 and the alpha value of employee intention to quit is .813 and in employee motivation the alpha value is .759 thus the results meets the standard requirements in this reliability assessment

\section{Convergent validity}

In convergent each of variables was analyzed by performing factor analysis. Factor analysis was applied on all 15 items in which 4 items were on diversity management and 3 items were on employee intention to quit and 5 items were on employee motivation. Instrument was consisting of 1 independent variable, 1 dependent variable and 1 mediating variable. 


\begin{tabular}{ccccc} 
Table \# 03 & Summary of KMO Bartlett's test & & \\
Variables & & \multicolumn{2}{c}{ Bartlett's Test } \\
\hline & DMO & df & Sig \\
& Diversity management & .581 & 6 & .000 \\
Employee intention to quit & .685 & 3 & .000 \\
Employee motivation & .755 & 10 & .000 \\
\hline
\end{tabular}

In the (Table\#03) results of validity test, the significance is .000 and the $\mathrm{df}$ is .581 of diversity management and .685 in employee intention to quit and .755 of employee motivation so the assumption of factor analysis was fulfilled. Assumption implies that KMO value must be above .50 and Bartlett's test is significant, the result shows that the instrument is valid.

\begin{tabular}{lllll}
\hline & & Correlations & & \\
DM & DM & EM & TI \\
& Pearson Correlation & 1 & $.183^{*}$ & $-.264^{* *}$ \\
& Sig. (2-tailed) & & .044 & .003 \\
& $\mathrm{~N}$ & 121 & 121 & 121 \\
$\mathrm{EM}$ & Pearson Correlation & $.183^{*}$ & 1 & $-.261^{* *}$ \\
& Sig. (2-tailed) & .044 & & .004 \\
& $\mathrm{~N}$ & 121 & 121 & 121 \\
$\mathrm{TI}$ & Pearson Correlation & $-.264^{* *}$ & $-.261^{* *}$ & 1 \\
& Sig. (2-tailed) & .003 & .004 & 121 \\
\hline
\end{tabular}

That according to persons correlation there exist negative Correlation between diversity management and the employee intention to quit which is $(-.26)$ as $r$ value is between -1 to +1 and $p$ value is less than 0.05 significant and there is positive correlation between diversity management and employee motivation which is (.18) as $\mathrm{r}$ value is between -1 to +1 and $p$ value is less than 0.05 significant at the 0.01 level (2-tailed)

Correlation is significant at the 0.05 level (2-tailed).

Correlation is significant at the 0.01 level ( 2 tailed)

\section{REGRESSION}

$\begin{array}{ccc}\text { Table \# 05 } & \text { MODEL SUMMARY } \\ \text { MODEL } & \text { R } & \text { R SEQUARE }\end{array}$

\begin{tabular}{rrrrr}
\hline 1 & .264 & .070 & .062 & .81741 \\
\hline
\end{tabular}

A. Predictor.DM
le $\# 05$ shows the value of $r$ square .070 represents that the variation occurred in the dependent variable (turn over) due to independent variable (employee motivation).

Table \# 06

ANOVA

\begin{tabular}{|c|c|c|c|c|c|c|}
\hline Model & & $\begin{array}{c}\text { Sum of } \\
\text { SQUARE }\end{array}$ & Df & $\begin{array}{l}\text { Mean } \\
\text { SQUARE }\end{array}$ & f & Sig. \\
\hline & Regression & 5.980 & 1 & 5.980 & 8.950 & $.003^{b}$ \\
\hline \multirow[t]{2}{*}{5} & residual & 79.511 & 119 & .668 & & \\
\hline & TOTAL & 85.491 & 120 & & & \\
\hline
\end{tabular}

The Table\#6 ANOVA shows the significance as the $\mathrm{p}$ value is $<.05$ and this depicts that the research model is fit.

Table \# 07

MODEL

\begin{tabular}{lcc} 
& (constant) & $\mathbf{4 . 0 1 8}$ \\
1 & DM & -.243 \\
\hline
\end{tabular}

\section{Coefficients}

STANDARDIZED T Tig.

Coefficients

Beta

$\begin{array}{rr}19.680 & .000\end{array}$

a. dependent variable:TI

The table 27 depicts that if one unit increase in the diversity management occur then it will cause -.264 unit decrease in the turn over intention 


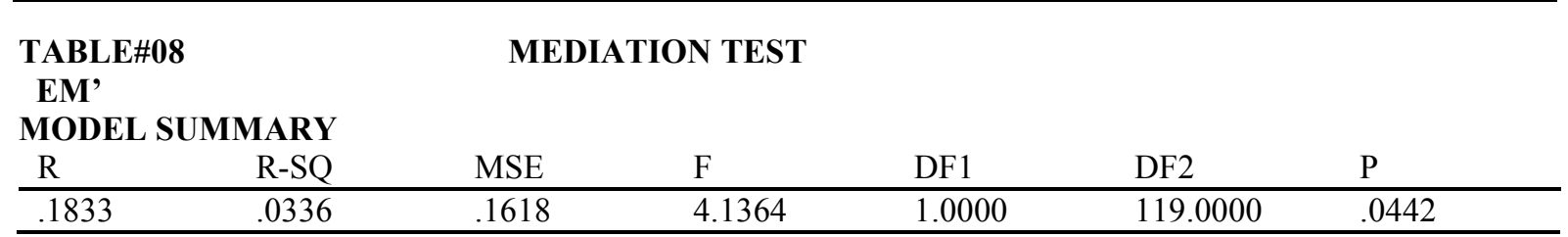

\section{MODEL}

\begin{tabular}{lllllll} 
& COEFF & SE & T & P & LLCI & ULCI \\
\hline CONSTANT & 1.5022 & .1005 & 14.9523 & .0000 & 1.3033 & 1.7012 \\
DM & .0813 & .0400 & 2.0338 & .0442 & .0021 & .1605 \\
\hline
\end{tabular}

The results show that diversity management and employee motivation has significant relationship as the r-sq value is (.0336) and $\mathrm{p}$ value is less than .05 that shows the significant relationship.

TI

\begin{tabular}{lllllll} 
Table \#09 & \multicolumn{7}{c}{ MODEL SUMMARY } \\
$\mathbf{R}$ & $\mathrm{R}-\mathrm{sq}$ & $\mathrm{MSE}$ & $\mathrm{F}$ & $\mathrm{DF} 1$ & $\mathrm{Df} 2$ & $\mathrm{P}$ \\
\hline $\mathbf{3 4 1 4}$ & .1166 & .6400 & 7.7865 & 2.0000 & 118.0000 & .0007 \\
\hline MODEL & & & & & & \\
& COEFF & SE & $\mathrm{T}$ & $\mathrm{P}$ & LLCI & ULCI \\
\hline CONSTANT & 4.7016 & .3390 & 13.8674 & .0000 & 4.0302 & 5.3729 \\
EM & -.4551 & .1823 & -2.4960 & .0139 & -.8161 & -.0940 \\
\hline
\end{tabular}

The result shows that employee motivation and turnover intention has the significant relationship as the R-sq value is (.1166) and the $\mathrm{p}$ value is less than 0.05 that shows the significant relationship.

\section{TABLE\#10}

\begin{tabular}{lllll}
\multicolumn{1}{l}{ INDIRECT EFFECT(S) OF X ON Y: } & & \\
& EFFECT & BOOSTSE & BOOTLLCI & BOOTULCI \\
\hline $\mathrm{EM}$ & -.0370 & .0217 & -.0869 & -.0028
\end{tabular}

Table\# 10 shows that bootLLCI is (-.0869) and BootULCI is (-.0028) which explain that the mediation exist in this indirect effect.

\section{Discussion}

With the passage of time DM has become necessity for every organization. The purpose of this study is to investigate the effects of DM on employee intention to quit with the mediating role of EM. According to the (Nederveen Pieterse, Van Knippenberg et al. 2013), the diversity measures (education and age) were significantly positively related to the team identification collectively and team performance.

However, according to this study the results show that DM and turn over intention has significant positive relationship. As Implementation of diversity policies can help to reduce turn over intention according to the wise and tschirhart (2000) the meta study that contain the evidence for diversity programs that reduce the turnover intention and actual turnover. By studying the EM, the employee behavior such as readiness which reflects the employee outcome in any organization that further lead to their tendency to continue (Lorse, \& Boivin, 2010).

As results of present studies show that EM has the negative relationship with turnover intention which implies that low motivation level can increase turnover intention to leave the organization. Current study shows that motivation mediates the relationship between turnover intention and DM. Explanation for this diversitymotivation-intention relationship is that employee behavior matter that any organization supports the employee via DM and can boost up the motivation level and thereby reduces the turnover intentions. These results make sense according to(Dysvik and Kuvaas 2008) motivation has the partial mediation relationship between perceived equal training opportunities and turnover intention.

\section{Conclusion}

The results of this study show that by implementing diversity policies and activities can help to increase motivation level of employees and can automatically reduce the turn over intention in any organization. Somehow, this study helps us to understand that how the diversity management can affect employee behavior and organizational outcomes. HR department can play a vital role in maintaining and developing diversity policies and practices.

There is several limitations of this study. First of all employee behavior and motivation is different from sector to sector so study can be conducted according to sector to sector and results may varies. In present study the single mediating variable was discussed, motivation variable. It would better to study the other variable as moderator or mediating the effect of diversity management and employee intention to quit. Organizational polices 
reflect the employees' interest and retention in organization. So, if employees are not satisfied with the organizational policies the policies should be changed.

Results show that mediation exists in diversity management and turnover intention that can help to reduce turnover intention in any organization that can lead to the positive change in the organization

\section{References}

Armstrong, C., Flood, P.C., Guthrie, J.P., Liu, W., MacCurtain, S. and Mkamwa, T. (2010), "The impact of diversity and equality management on firm performance: beyond high performance work systems", Human Resource Management, Vol. 49 No. 6, pp. 977-998

Beach, R., Brereton, D., Cliff, D., 2003. Workforce Turnover in FIFO Mining Operations in Australia: An Exploratory Study. Centre for Social Responsibility in Mining, Sustainable Minerals Institute, University of Queensland, Brisbane,

Bridgstock, R., Lettice, F. and Özbilgin, M. (2010), "Diversity management for innovation in social enterprises in the UK”, Entrepreneurship \& Regional Development, Vol. 22 No. 6, pp. 557-574.

Evans, C. (2014), "Diversity management and organizational change", Equality, Diversity and Inclusion: An International Journal, Vol. 33 No. 6, pp. 482-493.

Galbreath, J. (2010). Drivers of corporate social responsibility: The role of formal strategic planning and firm culture.

Griggs, L.B., 1995. Valuing Diversity: New Tools for a New Reality. Mc Graw-Hill

Agarwal, U. A. and S. Bhargava (2014). "The role of social exchange on work outcomes: a study of Indian managers." The International Journal of Human Resource Management 25(10): 1484-1504.

Amabile, T. M. (1993). "Motivational synergy: Toward new conceptualizations of intrinsic and extrinsic motivation in the workplace." Human resource management review 3(3): 185-201.

Armstrong-Stassen, M. (2001). "Reactions of older employees to organizational downsizing: The role of gender, job level, and time." The Journals of Gerontology Series B: Psychological Sciences and Social Sciences 56(4): P234-P243.

Boshoff, C. and J. Allen (2000). "The influence of selected antecedents on frontline staff's perceptions of service recovery performance." International Journal of Service Industry Management 11(1): 63-90.

Chen, P.-J. and Y. Choi (2008). "Generational differences in work values: a study of hospitality management." International Journal of Contemporary Hospitality Management 20(6): 595-615.

Cho, Y. J. and G. B. Lewis (2012). "Turnover intention and turnover behavior: Implications for retaining federal employees." Review of Public Personnel Administration 32(1): 4-23.

Choi, Y. and D. R. Dickson (2009). "A case study into the benefits of management training programs: Impacts on hotel employee turnover and satisfaction level." Journal of Human Resources in Hospitality \& Tourism 9(1): 103-116.

Deci, E. L. and R. M. Ryan (2004). Handbook of self-determination research, University Rochester Press.

Dirks, K. T. and D. L. Ferrin (2002). "Trust in leadership: Meta-analytic findings and implications for research and practice." Journal of applied psychology 87(4): 611.

Dysvik, A. and B. Kuvaas (2008). "The relationship between perceived training opportunities, work motivation and employee outcomes." International Journal of Training and Development 12(3): 138-157.

Furunes, T. and R. J. Mykletun (2007). "Why diversity management fails: Metaphor analyses unveil manager attitudes." International Journal of Hospitality Management 26(4): 974-990.

GETACHEW, M. (2017). FACTORS CONTRIBUTE TO EMPLOYEE TURNOVER INTENTION IN THE CASE OF ETHIOPIAN ROAD AUTHORITY, St. Mary's University.

Green, K. A., et al. (2002). "Diversity in the workplace: Benefits, challenges, and the required managerial tools." University of Florida 1(4): 1-3.

Hinkin, T. R. and J. B. Tracey (2000). "The cost of turnover: Putting a price on the learning curve." Cornell hotel and restaurant administration quarterly 41(3): 14-21.

Houkes, I., et al. (2003). "Specific determinants of intrinsic work motivation, emotional exhaustion and turnover intention: A multisample longitudinal study." Journal of Occupational and organizational Psychology 76(4): $427-450$

Hsiao, A., et al. (2015). "Perceived organizational diversity and employee behavior." International Journal of Hospitality Management 48: 102-112.

Kim, B. P., et al. (2009). "Moderating effects of gender and organizational level between role stress and job satisfaction among hotel employees." International Journal of Hospitality Management 28(4): 612-619.

Kundu, S. C., et al. (2017). "EFFECT OF DIVERSITY MANAGEMENT ON EMPLOYEES'INTENTION TO QUIT: MEDIATING ROLE OF EMPLOYEE MOTIVATION." Journal of Strategic Human Resource Management Volume 6(3).

Langford, P. H. (2009). "Measuring organisational climate and employee engagement: Evidence for a 7 Ps model 
of work practices and outcomes." Australian Journal of Psychology 61(4): 185-198.

Magd, H. (2003). "Management attitudes and perceptions of older employees in hospitality management." International Journal of Contemporary Hospitality Management 15(7): 393-401.

Magoshi, E. and E. Chang (2009). "Diversity management and the effects on employees' organizational commitment: Evidence from Japan and Korea." Journal of World Business 44(1): 31-40.

Maslach, C., et al. (2001). "Job burnout." Annual review of psychology 52(1): 397-422.

Mayer, R. C. and J. H. Davis (1999). "The effect of the performance appraisal system on trust for management: A field quasi-experiment." Journal of applied psychology 84(1): 123.

Moynihan, D. P. and N. Landuyt (2009). "How do public organizations learn? Bridging cultural and structural perspectives." Public Administration Review 69(6): 1097-1105.

Nederveen Pieterse, A., et al. (2013). "Cultural diversity and team performance: The role of team member goal orientation." Academy of Management Journal 56(3): 782-804.

Patrickson, M., et al. (2001). Managing diversity: an Asian and Pacific focus, John Wiley \& Sons.

Pinder, C. C. (2014). Work motivation in organizational behavior, Psychology Press.

Royalty, A. B. (1998). "Job-to-job and job-to-nonemployment turnover by gender and education level." Journal of labor economics 16(2): 392-433.

Ryan, R. M. and E. L. Deci (2000). "Intrinsic and extrinsic motivations: Classic definitions and new directions." Contemporary educational psychology 25(1): 54-67.

Singal, M. (2014). "The business case for diversity management in the hospitality industry." International Journal of Hospitality Management 40: 10-19.

Skudiene, V. and V. Auruskeviciene (2012). "The contribution of corporate social responsibility to internal employee motivation." Baltic journal of management 7(1): 49-67.

Sourouklis, C. and D. Tsagdis (2013). "Workforce diversity and hotel performance: A systematic review and synthesis of the international empirical evidence." International Journal of Hospitality Management 34: $394-$ 403.

Tzafrir, S. S., et al. (2004). "The consequences of emerging HRM practices for employees' trust in their managers." Personnel Review 33(6): 628-647.

Wang, C.-J. (2016). "Does leader-member exchange enhance performance in the hospitality industry? The mediating roles of task motivation and creativity." International Journal of Contemporary Hospitality Management 28(5): 969-987.

Winter, T. (2009). "Asian tourism and the retreat of anglo-western centrism in tourism theory." Current Issues in Tourism 12(1): 21-31.

Yang, J.-T., et al. (2012). "Qualitative examination of employee turnover and retention strategies in international tourist hotels in Taiwan." International Journal of Hospitality Management 31(3): 837-848. 